\title{
Pandemics, crisis conjunctures, and professional practices: what is the role of nursing with regard to Covid-19?
}

\author{
Pandemia, conjunturas de crise e prática profissional: qual \\ o papel da enfermagem diante da Covid-19? \\ Pandémia, conjuncturas de crisis y práctica profesional: cual \\ es el rol de la enfermería frente a la Covid-19?
}

\section{Helena Maria Scherlowski Leal David Sonia Aciolia \\ Maria Rocineide Ferreira da Silva ${ }^{b}$ \\ Osvaldo Peralta Bonettic Hozana Passos $^{\mathrm{d}}$}

\begin{abstract}
How to cite this article: David HMSL, Acioli S, Silva MRF, Bonetti OP, Passos H. Pandemics, crisis conjunctures, and professional practices: what is the role of nursing with regard to Covid-19? Rev Gaúcha Enferm. 2021;42(spe):e20190254 doi: https://doi.org/10.1590/19831447.2021.20190254
\end{abstract}

Universidade do Estado do Rio de Janeiro (UERJ) Faculdade de Enfermagem, Programa de PósGraduação em Rio de Janeiro, Rio de Janeiro, Brasil.

${ }^{\text {b }}$ b Universidade Estadual do Ceará (UECE), Programa de Pós-Graduação em Cuidados Clínicos em Enfermagem e Saúde. Fortaleza, Ceará, Brazil.

' Fundação Oswaldo Cruz (FIOCRUZ), Brasília, Distrito Federal, Brasil.

¿ Prefeitura Municipal de Belo Horizonte. Belo Horizonte, Minas Gerais, Brasil.

\section{ABSTRACT}

Objetivo: Discutir o papel da enfermagem diante dos desafios políticos, econômicos e sanitários que configuram conjuntura de crise pela pandemia por Covid-19.

Método: Estudo de reflexão crítica de características analíticas, com base na epidemiologia crítica de matriz latino-americana e no conceito de determinação social da saúde.

Resultados: As questões centrais relativas ao cenário político-econômico e sanitário brasileiro são problematizadas, com destaque para 0 aprofundamento da desigualdade social. Debate-se o papel da enfermagem considerando os impactos na saúde destes trabalhadores, e a relevância da sua atuação nos diversos cenários de prática profissional e na defesa da proteção social. Conclusões: Reafirma-se o papel da enfermagem brasileira como prática social de defesa da vida e do acesso universal à saúde com vistas à conquista da justiça social.

Palavras-chave: Infecções por coronavírus. Pandemias. Política.

\section{ABSTRACT}

Objective: to discuss the role of Brazilian nursing to face political, economic and sanitary challenges that compose the crisis situation related to Covid-19 pandemics.

Methods: Critical-thinking study with analytics characteristics, based on latin-american critical epidemiology and on the concept of social determination of health.

Results: the central issues related to the Brazilian political-economic and health scenario are problematized, with emphasis on the impacts in terms of social inequality deepening. Nursing role is discussed considering the impacts in these worker's health, and the relevance of nurses'actions in the several professional practice scenarios to defend social protection.

Conclusions: the role of Brazilian nursing as a social practice for the defense of life and universal access to health is reaffirmed as a way of achieving social justice.

Keywords: Coronavírus infections. Pandemics. Nurses. Politics.

\section{RESÚMEN}

Objetivo: discutir el rol de la enfermería para enfrentar los retos políticos, económicos y sanitarios que configuran la situación de crisis en el contexto de la pandémia de Covid-19.

Método: Estudio de reflexión crítica con características analíticas, basada en la epidemiología crítica de matriz latinoamericana y en el concepto de determinação social da saúde.

Resultados: se problematizan los problemas centrales relacionados con el escenario político-económico y de salud brasileño, con énfasis en los impactos en términos de profundizar la desigualdad social. Discutiese el papel de la enfermería considerando los impactos en la salud de estos trabajadores y la relevancia de su desempeño en diferentes escenarios de práctica profesional y en la defensa de la protección social.

Conclusiones: se reafirma el papel de la enfermería brasileña como práctica social para la defensa de la vida y el acceso universal a la salud con miras a lograr la justicia social.

Palabras clave: Infecciones por coronavírus. Pandémias. Enfermería. Políitica. 


\section{IINTRODUCTION}

The year 2020, from its beginning, was loaded with symbols and meaning for nursing. It celebrated the bicentennial of the birth of Florence Nightingale, the woman who, together with Mary Seacole, was the pioneer and founder of modern nursing, both having acted in the care to wounded soldiers in the battlefields of the Crimean War during the $1850 \mathrm{~s}^{(1)}$.

Florence's contribution brought a deep impact to the public health of the world, from the hospital space to public health. Among her teachings and actions, some stand out, including the environmentalist theory, which includes practices until then neglected, such as highlighting the importance of isolation in taking care of the diseased, the use of statistical methods in the analysis and planning of health actions, the therapeutic role of the diet, of sanitation, of hygiene, of hand washing, and of ventilation, among other factors aimed at avoiding contagion. Florence was recognized and is considered by many to be the mother of epidemiology and of sanitary surveillance ${ }^{(1)}$.

Ironically, in the same year of the bicentennial of nursing, we were, abruptly, suddenly, and in a global scale, stricken by the biggest public health crisis of our generation. The propagation of the new virus from the coronavirus family has been ending millions of lives worldwide, including hundreds of health professionals, especially nurses. The Coronavirus Disease (COVID-19) pandemic, detected in China in December 2019, has been bringing health systems to collapse. In Brazil, we lost the opportune time frame to prevent the large-scale contagion and plan sanitary actions, when compared to Asian and European countries ${ }^{(2)}$. As a result, we see in front of us the frightening context of daily increases in cases and deaths.

In this setting, we feel instigated to revisit our history, our values, and the fundamental principles of our knowledge and our critical actions, thus, turning to elaborate this article, which seeks to contribute to raising questions about the practice and the main role of nursing in confronting the COVID-19 pandemic. The moment provokes many questions and reflections, such as: What level of importance have societies been giving to the way in which health is organized? What is our contribution and how has the situation of nurses been as they act to confront the pandemic? How do social inequalities show themselves in the dissemination and confrontation of the disease? Although it is not possible to analyze in depth all questions above, these are the issues that guide our reflection in this article, which seeks to discuss the role of nursing, considering the political, economical, and sanitary challenges that brought about this state of crisis, caused by the Covid-19 pandemic.
We start with an analysis of some processes that are in the origin or contribute to compose a social and sanitary framework filled with doubt, which shows historic inequalities. Our support is in the theoretical perspective of the Latin-American critical epidemiology, whose explanations about the health phenomena consider the levels of singular determination and conditioning, both particular and structural, of health problems ${ }^{(3)}$. The critique from this perspective, in the context of endemic-epidemic processes, have pointed out that forms such as contradictions and processes of exploration of work are anchored in certain models of development of Latin-American countries, which prevent the formation of more just and egalitarian societies ${ }^{(4)}$. Despite the challenge and the obvious limits of this analysis, since this theme is highly complex, we also want to raise the awareness of nursing professionals about the need for reflection, aiming to suggest that, in the context and in practice, the work of the nurse, especially in the field of Collective Health, should consider "the possibilities of affirming rights and defending public policies that favor the construction of healthy environments" 1 (5:225).

History shows that, as complex as they may be, crises too evanesce, when confronted critically, with common sense, science, critical looks, and windows of opportunities to overcome and advance. These are moments where there are opportunities for transformations that contribute to deal with distortions or problems that had been underestimated. Therefore, we feel urged to carry out this reflexive exercise, dealing with anxieties, fears, and with the urgency that the situation has been demanding from us, towards contributing to this veritable crusade that Brazilian nursing is going through.

\section{Political-economic and sanitary conjunctures in Brazil: one pandemic, multiple crises}

As this article is being produced, Brazil has exceeded 2 million confirmed cases of coronavirus, of the severe acute respiratory syndrome 2 (SARS-CoV-2), or COVID-19, and more than 80 thousand killed by the respiratory virus that spreads, as a pandemic, in all continents, since December 2019. Even with many questions and doubts, the management of the pandemic has been an experience of daily decision-making made by health professionals, managers, and the population.

The fast transmission between countries is attributed to the circulation of infected people, whether symptomatic or not, that were in contact with people in closed environments, thus facilitating the contagion, and the quickly installed community transmission. In Brazil, the first cases were identified and confirmed at the end of February 2020. 
Initially, the cases were related to people who returned from trips abroad, mainly from China, Italy, or the United States. In March 2020, the Ministry of Health identified the first community transmission in the country, in the city of São Paulo, and then in Rio de Janeiro(6).

Although we had relatively comfortable time to plan and implement preventive and political measures to control the pandemic, when compared to the situation of the first countries to experience it, our action was prejudiced by the political and institutional crises that we observe in the current federal government. There was an evident lack of support for the Ministry of Health by the Presidency of the Country, which publicly issued negligent statements ("it is just a little flu"). This lack of support led to a surprising exchange of Ministers of Health in the midst of what is being considered the moment of the greatest socio-sanitary gravity in this century ${ }^{(7)}$.

The Federal Government's main politicians stance regarding the severity of the pandemic has resulted in a process that is dubious to the need to implement measures of social isolation, and to a resistance to measures of economic and social support for workers during the crisis. The negative exposure of Brazil in the media and in the international scientific community has intensified day after day, as expressed by the publication of the editorial of the Lancet Magazine from May 7, dedicated solely and exclusively to a critique of the Brazilian response to the pandemic, in which it is said that "perhaps the greatest threat to the response to COVID-19 in Brazil is President Jair Bolsonaro"(8: 1461).

Thus, to analyze the measures in Brazil, we have multiple point of views. If we observe the beginning of the crisis, the Ministry of Health had an important guiding role in the implementation of social isolation. The ministry also initiated a policy of daily communication with society, announcing numbers of cases, information on the behavior of the disease, announcements of control, acquisition of protective equipment and mechanical ventilators, among others. There was an impression that the then Minister Mandetta himself, with the impact of the pandemic, had placed the neoliberal orientation of his management in quarantine, due to all the serious impacts to the Unified Health System (SUS), either due to the funding generated by the Constitutional Amendment 95 (EC 95), of which he was a strong supporter in the National Congress, be it deconstructing policies of profound significance for the access of the Brazilian population to health, especially those in situations of greater vulnerability, such as the dismantling of the Mais Médicos Program and the changes in Primary Care policy.

Based on the change of ministers, the evaluation of a large part of Brazilian society, expressed in the news media and by state managers, was that preventive measures were abandoned, purchases were canceled and the defense of social distancing has been weakened, all based on a false dichotomy between economics and health, influenced by the economic policy with support from the interests of the business and financial sector, and with a slow transfer of essential financial support to states and municipalities to help the fiscal deficit.

Although social distancing has been implemented (albeit partially), there has not been, so far, an active search for suspicious cases, monitoring of diagnosed case contacts or decentralized distribution of testing. Thus, due to underreporting, the number of cases in Brazil is, in projections, eight to ten times greater than the number of cases reported ${ }^{(9)}$.

There are those whose perspective is fueled by several xenophobic persecutory theories, such as the one that attributes the creation or nationality of the SARS-CoV-2 virus to the Chinese, because it was in that country that the first epidemic outbreak occurred. It is a vision stimulated, above all, by the economic base concerns of the sectors already mentioned, threatened by an economy that has already been staggering since 2019, and which, now, in the context of the pandemic, is practically stagnant ${ }^{(10)}$. In contrast, we have national and international studies, and a set of recommendations based on scientific evidence, which have not been adequately or completely followed by a large part of the population.

The moment has also shown the profound inequality in the living conditions of the Brazilian population: while a wealthy class and a working middle class with stable employment can mobilize diverse resources to meet the recommendations of social distance or isolation of suspicious cases, being able to follow the recommendations regarding personal hygiene measures, and having access to cultural and educational resources mediated by the internet, there is, on the other side, a huge contingent of people living in peripheral areas, densely populated, with the urban space occupied in a disorderly fashion, which depends on public transport and have no access to the internet, or accurate and fast information, among other problems ${ }^{(2)}$. It was not by chance that the first case of death in Brazil was of a black woman, a domestic worker who contracted the disease from her bosses, known to be contaminated and who had arrived from Italy; the second case was that of a doorman whose hospitalization was considered suspect to say the least, since he had not traveled abroad.

On one hand, there is the scientific community and health professionals, supported by state and municipal managers, who are concerned with the increase in cases, especially severe cases, that require hospitalization with highly 
complex care in ventilatory support, requiring resources not immediately available, of high cost and slow production. But on the other hand, there is the majority of the precarious, underemployed or unemployed working population, who survive at the expense of daily work and various agencies to obtain the resources that allow them to survive one day at a time, which imposes limits on thinking and practice the preventive actions recommended.

Adding to this situation of social injustice, in Brazil, although we have achieved in our constitution the right to a universal health system, inequality in the access to health services is inhumane. According to data from the National Registry of Health Establishments (CNES) of the Ministry of Health, we have 22.215 beds in Intensive Care Units (ICU) in Brazilian capitals, $42 \%$ of which are in the SUS network and $58 \%$ in the private sector. In SUS, the bed ratio per 10.000 inhabitants is 2.18 beds, while in the private sector, it is 6.95 . Considering that only $25 \%$ of the population have private health plans, the availability of ICU beds for SUS users is much lower than that of supplementary health. Although it is publicly stated that all lives matter, for the fragmented health system that exists in the country today, the lives of users of supplementary health are worth more than three times that of SUS users ${ }^{(11)}$.

According to data from the last Census of the Brazilian Institute of Geography and Statistics (IBGE), $6 \%$ of the Brazilian population live in slums or urban areas without urban infrastructure. In other words, more than 11 million citizens live in precarious conditions, cramped spaces with many residents, poorly ventilated and without access to basic sanitation. This data is from the continuous National Household Sample Survey (PNAD) 2019, from IBGE, which found that 9 million Brazilian households do not have access to the sewage network and that this number has been growing since 2016. The survey shows that the setting is more critical in the North Region, with $29.6 \%$ of households (1.6 million) without a sewage system and with waste dumping on the street or in nature. This percentage is higher than that of houses with access to the general sewage network, which is $27.4 \%$ (12).

The conjunction of multiple factors of political, economic, and social crisis is not a new element in the health debate. The rupture or wear of social ties, and the widening gap that separates the world's economic elites and the rest of the population, has been a topic of discussion for at least three decades. Health has been debated from this perspective, as a dimension of life that expresses the contradictions imposed by an environmentally and humanly predatory way of accumulating wealth. The environmental and human crimes under the responsibility of the mining company Vale and the pandemic by COVID-19 seem to show, now, in a more striking and dramatic way, the effects of this global development model, already expressed in other endemic-epidemic processes such as those of arboviruses transmitted by mosquitoes (dengue fever, Zika, Chikungunya), the persistence or reappearance of pulmonary tuberculosis, in addition to the recent pandemics of influenza A subtype H1N1, Severe Acute Respiratory Syndrome (SARS), and Middle East Respiratory Syndrome (MERS) ${ }^{(10)}$.

The pandemic is configured, therefore, as a context of multiple layers and processes of social and biological determination, affecting everyone, albeit unevenly. To what extent it will be possible to move forward in controling the determinants and conditions of this health crisis is what Brazilian society will have to answer soon.

\section{Nursing and pandemic in Brazil: who are we, what do we do?}

Regarding health professionals in general, and nursing professionals in particular, what dominates the debate is the restricted capacity of governments and public and private services to guarantee access to the appropriate Personal Protective Equipment (PPE) - debate more intensely present in the first period of the pandemic - and the regulations issued (which change according to the progress of the pandemic), are not always feasible for execution in health services. Situations such as the lack of space and adequate resources for the assistance, and the undersizing of the teams, demonstrate the limited response capacity of the health system in the face of a highly transmissible disease, in which there are cases that progress to a severe form of the illness. The Federative Units have chosen to issue their own regulations and guidelines, according to local and regional specificities. The quality and quantity of PPE has been questioned daily by professionals who work in direct care for suspects and patients. The health teams face doubts regarding the handling of suspected cases and, often, they are lost and without time at work to study technical notes, epidemiological bulletins and recommendations.

According to data from the Federal Nursing Council, the number of infected nursing professionals is high, with more than 20 thousand sick leave accumulated up to June 2020 and it is known that the number of cases is underreported. It is a reality that generates indignation and sadness, since care is central to our work, which is essential to save lives. It is also necessary to highlight our role in the implementation of SUS and in the search for the realization of the right to health, essential to the system and fundamental to the civilizing process of our country ${ }^{(13)}$. 
At the beginning of May 2020, Brazil ranked first in number of deaths of nursing and contaminated professionals among countries. The comparison of Brazilian and North American numbers explains this catastrophic setting for nursing. While here, on that date, we had surpassed the mark of 11 thousand deaths, more than 100 were from nursing professionals. In the USA, which had already exceeded 98 thousand deaths, 91 of these were from nursing professionals. It is possible to state that, in May, we had ten times more losses in Brazilian nursing than in the USA ${ }^{(14)}$.

The impact of this setting provokes us to reflect on what justifies this huge discrepancy and such losses. Is it the shortage of PPE? What will be the importance of factors such as vesting procedures, inadequate hospital structures, overload of work and extensive hours, insufficient testing for health teams, among others? How do these numbers articulate with the precariousness of the structures of health services, chronicled by the already mentioned lack of financing? Did the waiting time in Brazil allow these professionals to have access to adequate training to face this crisis? Will professional training to work in a pandemic, and at levels of complexity like those in an ICU, be sufficient in quality and quantity? How do the living and working conditions that professionals are subjected to affect their health?

We believe that, in reality, we have experienced conditions such as extensive and intensive daily workloads, exhausting working hours, low wages and the need to maintain several jobs, low or nonexistent support structure for rest in hospitals, psychological distress since long before the pandemic, among other problems ${ }^{(15)}$.

The role of nursing has been highlighted as part of the team that can save lives, specially given the seriousness of the situation. This performance, when published in the media and also when indicated in the regulations, is restricted to the service spaces, with the Primary Health Care (PHC) level responsible for receiving and screening suspicious cases, and the intermediate and high complexity levels, of receiving and developing care and therapeutic actions, according to the severity of the case. It should be emphasized that there is little questioning and that it is necessary to reorganize health services to respond to the pandemic, especially in the primary care network. The PHC territory is the primary locus for implementing educational and health surveillance measures, which are essential for health care and for the containment of the disease $\mathrm{e}^{(14)}$.

The public debate about the role of nursing in educational activities seems insufficient, as well as about the role of these professionals as an educator and mobilizer for the people. How can we articulate, in practice, our pedagogical role and the ability to mediate knowledge in support of population groups, together with the necessary technical action in a time of health emergency? How far is it possible to think of popular health education practices when we are in the eye of the hurricane of the pandemic of COVID-19? What is the role of the critical pedagogical and social practice of nurses in the face of a global and national political setting that points to the exhaustion of ways of living and of producing and distributing wealth? What is our role, as nurses committed to social justice, in the face of a national setting so adverse to the conquest and maintenance of social rights?

From the point of view of collective action, what has been shown to the world is the exhaustion of nursing professionals, bringing to atention already known situations of physical and emotional stress related to the work process of nursing teams. As a social issue, in addition to the ones caused by the pandemic, the conditions of work have worsened exponentially, following the increase in the curve of notified, hospitalized, serious cases and deaths of nursing professionals.

Since the beginning of the nursing profession, the concern with pathogens, separating more or less sick people, made an evident difference, especially when making this type of classification. And nursing has always been present in the management of care, even with their physical bodies, in the contexts of great epidemics and wars, being, however, at the same time, neglected and little heard. What role does nurses occupy during this pandemic? What is their skin color, what are their ways of living, what forms of exploitation do they suffer? Where do they come from? Their social class, race/ skin color? Sex? Gender? What questions has epidemiology been able to answer and what limitations are present in a mechanistic world with ready answers?

They are nurses, technicians, and nursing assistants who, in addition to working in hospitals, are on the so-called PHC front, which is in the various communities where necessities need to be highlighted and actions to satisfy them must be done. The breadth of nursing practice in PHC is evidenced and the qualification process needs to have scope to cover the educational aspect (an education based on the culture in which the user of the health system is inserted), in clinical practice (a practice capable of understand the dynamics of the territory where the population is located) and management (with the ability to generate and manage life-care situations).

Considering the theoretical bases that guide the practice of nursing in Public Health - which incorporates the performance in $\mathrm{PHC}$ - it is necessary to highlight that we have to act in all dimensions of health production, which implies the care of each individual and family, considered as singular entities, to communities and work institutions, in particular, and in the defense of public policies and social 
justice in the structural scope, without losing sight of the interdependence between these dimensions of practice ${ }^{(6)}$. We consider a more autonomous performance fundamental, supported by theoretical and methodological bases and instruments that allow professionals to advance in the analysis and in the ability to expand access to health care. We can mention, as an example, the care systematization model of the Theory of Praxic Intervention in Collective Health Nursing - TIPESC, which is still of limited use ${ }^{(16)}$. However, more than proposing a model or theory, it seems to us essential that nurses reassume the ability to autonomously define their ways of building their professional practice within the PHC.

In the COVID-19 context, the challenge imposed on Nursing is to "read the world" not only from within the health system, but looking at it as part of a process of struggles and disputes for the legitimation of diverse interests ${ }^{(17)}$. The same authors reaffirm the need for a critical conscience and the exercise of citizen vigilance where we do not assume the role of angels of salvation and that can even cost our lives, but of workers who have admittedly greater degrees of exposure and therefore require the State to assume the responsibility for these various bodies that are mobilized to face the disease. For popular health education, the concrete conditions of production and reproduction of life are important determinants and conditions for understanding ways of becoming ill and being healthy. It is necessary to reflect and consider that it has never been more important to reaffirm the struggles assumed as the ideals of Brazilian health reform as well as the recognition of dialogue as a fundamental principle in the struggle for life.

The health sector needs to advance in social protection, and most of its workforce, which is made up of nursing workers and professionals, must be recognized to develop what we call care. When it comes to quality of care, it is necessary to turn our attention to the quality of life of those who provide this assistance. The right of the Brazilian population to care and health is linked to the living and working conditions of health and nursing workers.

\section{FINAL CONSIDERATIONS}

By bringing the main elements that characterize the structural dimension of the current pandemic setting, we opted for a critical base, having as a background the ethical-political principles of universal access and broad right to health, and the professional bases defense of life, which understands nursing as a social practice, in addition to a profession or work. In this sense, we highlight some facts that seem to contribute to the weakening of social and institutional relations that affect the capacity of SUS to respond to the pandemic.
This is a study whose objective does not allow for conclusive analyzes, but only to raise issues about the conjuncture, bringing additional questions that provoke the critical reflection of Brazilian nurses. However, it is also necessary to advance concrete proposals for the organization of nursing work, considering the theoretical and methodological constructions already produced for the systematization of care, not forgetting that "sustainability is given by the conscious participation of the subjects of the transformation processes, changes these which are true, profound, intelligent, creative and human"(16).

The role of nursing in caring for sick people or those suspected of having COVID-19 infection has been highlighted in terms of the necessary technical and human competence for agile and safe care. But in recent weeks it has become increasingly clear that the role of nurses as a mediators between families and people hospitalized with COVID-19 is essential to reduce the feeling of loneliness and fear of isolated patients cared by professionals whose eyes are barely visible. This humanistic competence is not dissociated from the ethical-political competence and the pedagogical role of nursing practice.

As educators and popular knowlegde disseminators, and as activists in favor of the universal right to health, it is time to articulate, as a category, with the various sectors of civil society (which attribute to us the figure of heroes and heroines of the pandemic), to lead discussions and mobilizations around guaranteeing a strong state, defending the public, universal and equitable public health system, strengthening primary care as a guiding principle for comprehensive care strategies and combating the precarious nature of health work.

We still need to think and rescue, in the social memory of nursing, who are or were the protagonists of care. Here, we refer to the visibility around the figure of Florence Nightingale, at the same time that Mary Seacole's invisibility in the Crimean War took place. In that context, as in the current one, of war and struggle for the lives of sick people and caregivers, the one who came from London, white and from a privileged social class, ended up in evidence. Mary, who came from Jamaica, black, low social class, was not even mentioned. Perhaps this memory can teach us to deal with this pandemic, and to strengthen our social role.

At such a critical moment, materialization of ideas and an appropriate mix of propositions, in addition to being necessary, are urgent. Remembering Paulo Freire, teaching requires embodiment by example. The time comes when we are asked what we learn, but perhaps the most important thing is to understand how we learn, and how we reproduce that which we learned. Perhaps the discovery of how, will lead us to produce the new, for the new revealed challenge that inhabits the daily services. 


\section{REFERENCES}

1. Martins DF, Benito LAO. Florence Nightingale e as suas contribuições para 0 controle das infecções hospitalares. Univ Ciênc Saúde. 2016;14(2):153-66. doi: https://doi.org/10.5102/ucs.v14i2.3810

2. Rafael RMR, Neto M, Carvalho MMB, David HMSL, Acioli S, Faria MGA. Epidemiology, public policies and Covid-19 pandemics in Brazil: what can we expect? Rev Enferm UERJ. 2020;28:e49570. doi: http://doi.org/10.12957/ reuerj.2020.49570

3. Castellanos PL. Sobre el concepto de salud-enfermedad: descripción y explicación de la situación de salud. Bol Epidemiol OPS. 1994 [cited 2020 Jun 10];10(4):1-7. Available from: https://iris.paho.org/bitstream/handle/ 10665.2/32628/8366.pdf? sequence $=1$ \&isAllowed $=y$

4. Breilh J. La determinación social de la salud como herramienta de transformación hacia una nueva salud pública (salud colectiva). Rev Fac Nac Salud Pública. 2013 [cited 2020 Jul 22];31(1):13-27. Available from: http://hdl.handle. net/10644/3524

5. Peduzzi M, Silva AM, Lima MSDS. Enfermagem como prática social e trabalho em equipe. In: Soares CB, Campos CMS, organizadores. Fundamentos de saúde coletiva e o cuidado de enfermagem. Barueri: Manole; 2013. p. 227-44.

6. Candido DDS, Watts A, Abade L, Kraemer MUG, Pybus OG, Croda J, et al. Routes for Covid-19 importation in Brazil. J Travel Med. 2020;27(3):1-3. doi: https:// doi.org/10.1093/jtm/taaa042

7. Croda JHR, Garcia LP. Immediate health surveillance response to COVID-19 epidemic. Epidemiol Serv Saude. 2020;29(1):e2020002. doi: https://doi. org/10.5123/s1679-49742020000100021

8. Covid-19 in Brazil: "so what?" [editorial]. Lancet. 2020; 395(10235):1461. doi: https://doi.org/10.1016/S0140-6736(20)31095-3

9. Ribeiro LC, Bernardes AT. Estimate of underreporting of COVID-19 in Brazil by Acute Respiratory Syndrome hospitalization reports [Internet]. Belo Horizonte: Universidade Federal de Minas Gerais, Centro de Desenvolvimento e Planejamento Regional da UFMG; 2020 [cited 2020 Jun 10]. Available from: https://www. cedeplar.ufmg.br/noticias/1234-nota-tecnica-estimate-of-underreporting-ofcovid-19-in-brazil-by-acute-respiratory-syndrome-hospitalization-reports
10. A Terra é Redonda [Internet]. c2020 [citado 2020 Jun 10]. Narvai PC. Terraplanismo epidemiológico; [about 1 screen]. Available from: https:// aterraeredonda.com.br/terraplanismo-epidemiologico

11. Associação Brasileira de Saúde Coletiva [Internet]. Rio de Janeiro: ABRASCO; c2020 [citado 2020 jun 10]. Silva GA, Guimarães R. A hipocrisia nos leitos de UTl; [about 1 screen]. Available from: https://www.abrasco.org.br/site/ noticias/opiniao/a-hipocrisia-nos-leitos-de-uti-artigo-de-gulnar-azevedosilva-e-reinaldo-guimaraes/47213/

12. Instituto Brasileiro de Geografia e Estatística [Internet]. Rio de Janeiro: IBGE; c2020 [cited 2020 Jun 10]. Pesquisa Nacional por Amostra de Domicílios Contínua - PNAD Contínua; [about 1 screen]. Available from: https:// www.ibge.gov.br/estatisticas/sociais/trabalho/17270-pnad-continua. html?edica $=27258 \& \mathrm{t}=$ sobre

13. Conselho Federal de Enfermagem (BR) [Internet]. Brasília (DF); COFEN; 2020 [cited 2020 Jun 10]. Brasil ultrapassa EUA em mortes de profissionais de Enfermagem por Covid-19; [about 1 screen]. Available from: http://www.cofen. gov.br/brasil-ultrapassa-eua-em-mortes-de-profissionais-de-enfermagempor-covid-19_79624.html

14. Associação Brasileira de Saúde Coletiva [Internet]. Rio de Janeiro: ABRASCO; c2020 [cited 2020 Jun 10]. Machado MH. Profissionais de saúde em tempos de Covid-19; [about 1 screen]. Available from: https://www.abrasco.org.br/ site/sem-categoria/maria-helena-machado-publica-artigo-profissionais-desaude-em-tempos-de-covid-19/46045/

15. Azevedo BDS, Nery AA, Cardoso JP. Occupational stress and dissatisfaction with quality of work life in nursing. Texto Contexto Enferm. 2017;26(1):e3940015. doi: https://doi.org/10.1590/0104-07072017003940015

16. Egry EY, Fonseca RMGS, Oliveira MAC, Bertolozzi MR. Nursing in Collective Health: reinterpretation of objective reality by the praxis action. Rev Bras Enferm. 2018;71(Suppl 1):710-5. doi: https://doi.org/10.1590/0034-71672017-0677

17. David HMSL, Bonetti OP, Silva MRF. A Enfermagem brasileira e a democratização da saúde: notas sobre a Política Nacional de Educação Popular em Saúde. Rev Bras Enferm. 2012;65(1):179-85. doi: https://doi.org/10.1590/ S0034-71672012000100026

\section{- Corresponding author:}

Helena Maria Scherlowski Leal David

helenalealdavid@gmail.com

\section{Editor-in-chief:}

Maria da Graça Oliveira Crossetti 